ISSN: 2146-3042

DOI: $10.25095 /$ mufad.535948

\title{
Zaman Sürücülü Faaliyet Tabanlı Maliyetleme Sistemi: Bir Mermer İşletmesi Uygulaması *
}

\author{
Gamze CANER ${ }^{* *}$
}

\section{$\ddot{O Z E T}$}

Son yıllarda meydana gelen teknolojik yenilikler ile birlikte küresel rekabet ortamında faaliyet gösteren işletmelerin ürettikleri mamul ve hizmetlerin maliyet yapıları da değiş̧mektedir. Üretimde iş gücünün yerini otomasyonun alması sonucunda, toplam üretim maliyetleri içerisinde yer alan iş̧̧ilik maliyetleri azalmakta; buna karşıllk genel üretim maliyetleri artış göstermektedir. Bu bağlamda, genel üretim maliyetlerinin üretilen mamul ve hizmetlere yüklenmesi büyük önem teşkil etmektedir. Modern üretim ortamlarında geleneksel üretim ortamlarının ihtiyaçları doğrultusunda geliştirilmiş olan geleneksel maliyetleme sistemlerinin kullanılması hatalı maliyet bilgisine neden olmakta; hatalı maliyet bilgileri kullanılarak alınan stratejik yönetim kararlart ise işletmeleri büyük risklere sürüklemektedir. Bu çalışmada "Zaman Sürücülü Faaliyet Tabanlı Maliyetleme sistemi" hakkinda bilgi verilmekte ve olay çalışması yöntemi kullanılarak bir mermer sanayi işletmesinde uygulanabilirliği araştırılmaktadır.

Anahtar Kelimeler: Maliyet Muhasebesi, Faaliyet Tabanl Maliyetleme Sistemi, Zaman Sürücülü Faaliyet Tabanl Maliyetleme Sistemi, Mermer.

JEL Siniflandirmast: M41, L61, D24.

\section{Time-Driven Activity Based Costing: An Application in a Marble Enterprise}

\section{ABSTRACT}

In recent years, the cost structure of products and services of the enterprises, which endeavor to proceed their activities in global competition environment, has been changed. As a consequence of the technological evolution, machines have substituted laborer; thus labor costs of products have been decreasing in the favor of overhead costs. In this context, allocating overheads costs accurately to cost objects has become very important. Traditional costing systems, which have been developed for the requirement of traditional manufacture environment, can not provide accurate cost information under new circumstances. Inaccurate cost information produced by traditional costing systems leads enterprises faulty and precarious strategical management decisions. The main objective of this study is to explore feasibility of "Time-Driven Activity-Based Costing" (TDABC) by using case study method in a marble manufacturing enterprise.

Keywords: Cost Accounting, Activity-Based Costing, Time-Driven Activity-Based Costing, Marble. Jel Classification: M41, L61, D24.

\footnotetext{
* Bu çalışma, Gamze Caner'in 2017 yılında Arel Üniversitesi Sosyal Bilimler Enstitüsünde savunmuş olduğu "Zaman Sürücülü Faaliyet Tabanlı Maliyetleme Sistemi ve Bir Üretim İşletmesi Uygulaması" adlı doktora tezinden üretilmiştir.

** Dr., gamzeozturk87@gmail.com, ORCID ID: 0000-0001-5959-5107.
} 


\section{GíRiş}

Teknolojik gelişmelerin ve rekabetin artarak devam ettiği günümüz iş dünyasında faaliyet gösteren işletmelerin, ürettikleri mamul ve/veya hizmetlerin maliyetlerini tam ve doğru şekilde belirleyebilmeleri, işletmelerin geleceği açısından oldukça büyük önem arz etmektedir. Mamul ve/veya hizmetlerin maliyetlerinin doğru şekilde belirlenmesi, işletmelerin karllıkları, bütçeleme, fiyat belirleme, üretilecek mamul ve hizmetlerin karmasının belirlenmesi ve yönetimin geleceğe yönelik alacağı diğer önemli yatırım ve operasyon kararlarını büyük ölçüde etkilemektedir.

Geleneksel üretim ortamlarının ihtiyaçlarını karşılayacak biçimde tasarlanmış olan geleneksel hacim tabanlı maliyetleme sistemleri otomasyona dayalı modern üretim dünyasında işletmelere mamul ve/veya hizmet maliyet bilgisi üretmede yetersiz kalmaktadır. $\mathrm{Bu}$ sebeple 1980'li yıllarda Robin Cooper ve Robert S. Kaplan öncülüğünde ABD'de geliștirilen "Faaliyet Tabanlı Maliyetleme Sistemi" (FTM) üretilen mamul/hizmet maliyetlerinin doğru ve eksiksiz sonuçlar vermesini amaçlayan bir maliyetleme yöntemidir. Bununla birlikte FTM sisteminin kurulum ve güncellemesinde yaşanan zorluklar, karşılaşılan yüksek maliyetler ve maliyet sürücüsü seçiminde karşılaşılan güçlükler sonucunda Kaplan ve Anderson tarafindan geliştirilen "Zaman Sürücülü Faaliyet Tabanlı Maliyetleme" (ZSFTM) sistemi, klasik FTM sisteminin işletmelere sağladığı avantajlara sahip olmakla birlikte dezavantajlarıı ortadan kaldırmayı hedefleyen yeni bir maliyetleme sistemi olarak karşımıza çıkmaktadır.

$\mathrm{Bu}$ çalışmanın amacı, ZSFTM sistemini mermer sanayi sektöründe faaliyet gösteren bir örnek işletme üzerinde uygulayarak mamullerin maliyet bilgilerini hesaplamak ve işletmeye sağlayacağı avantajları araştırmaktır. Bu bağlamda, çalışmada öncelikle FTM ve ZSFTM sistemlerinin teorisi üzerinde durulmuştur. Daha sonra, ZSFTM sistemi örnek işletmede uygulanmış ve ulaşılan sonuçlar değerlendirilmiş̧ir.

\section{FAALIYET TABANLI MALIYETLEME SISTEMI (FTM)}

Günümüzün küresel boyutta şiddetli rekabet ortamında faaliyet gösteren işletmeler, değişen çevre koşullarını göz önünde bulundurarak faaliyetlerine devam etmek durumundadır. İşletmelerin öncelikli hedefi kar elde etmek ve karlılı düzeylerini sürekli biçimde arttrrmaktır. Geleneksel üretim ortamlarından farklı biçimde küresel rekabet ortamında işletmeler, mevcut ve potansiyel müşterilerinin ihtiyaç ve beklentilerini gerçekleştirecek, hatta bu beklenti ve ihtiyaçların ötesine geçirecek yeni ve farklı mamul ve hizmetleri kalitelerinden ödün vermeden geliştirmek ve üretmek durumundadır. (Kaygusuz, 2007: 139) Teknolojik gelişmeler maliyet ve yönetim muhasebesi alanında da yeni ve farklı yaklaşımların geliştirilmesini zorunlu hale getirmekte; işletme yönetiminin muhasebe sisteminden ve maliyet muhasebesinden beklentilerinin artmasina neden olmaktadır. (Gersil, 2007: 107; Pawłyszyn, 2017: 135) İşletmeler sahip oldukları rekabet güçlerini kaybetmemek adına hitap ettikleri müssteri kitlesini elinde tutmanın yanı sıra müşterilerine değer katarak nasıl daha büyük ve daha karlı müşteriler haline getirebileceklerini de belirlemek durumundadır. (Cokins, 2015: 23)

Üretim maliyetleri; direkt ilk madde ve malzeme, direkt işçilik ve genel üretim maliyetlerinden oluşmaktadır. Direkt ilk madde ve malzeme maliyetleri, üretim hacmine bağlı 
olarak değişkenlik gösterir. Direkt işçilik maliyetleri üretimde çalşsan işçilerin maliyetlerinden oluşmaktadır ve değişken özellik sergilemektedir. Direkt ilk madde ve malzeme ve direkt işçilik dışında kalan tüm üretim maliyetleri genel üretim maliyetlerini oluşturur. Direkt ilk madde ve malzeme ve direkt işçilik maliyetleri direkt maliyetler iken, genel üretim maliyetleri endirekt maliyetlerdir. (Posey ve Roth, 1986: 12)

20. yüzyılın başlangıcında genel olarak toplam üretim maliyetlerinin \% 50'si direkt işçilik maliyeti (DİM), \% 35'i direkt ilk madde ve malzeme Maliyeti (DİMM) ve \% 15'i genel üretim maliyeti şeklinde (GÜM) meydana gelmekte iken bu durum günümüzde toplam üretim maliyetlerinin ortalama \% 60'1 GÜM, \%30'u DİMM ve \% 10'u DİM'den oluşacak şekilde gerçekleşmektedir. (Kaygusuzoğlu, 2010: 242) Genel üretim maliyetlerinin toplam maliyet unsurları içerisindeki payının giderek artması sonucunda, bu maliyetlerin mamul ve hizmetlere yüklenmesinde modern maliyet yöntemlerinin kullanılması önemlilik arz etmektedir. (Özkan ve Karaibrahimoğlu, 2013: 421)

Geleneksel hacim tabanl maliyetleme sistemlerinin mamul ve hizmetlerin maliyetlerinin hesaplanmasında hatalara yol açması sonucunda geliştirilen modern maliyetleme sistemlerinden biri olan FTM sistemini Bharara ve Lee (1996, s.1110) faaliyetlerin, kaynakların ve maliyet öznelerinin maliyetlerini ve performanslarını ölçümleyebilen, kaynakların maliyetini faaliyetlere dağıtan, faaliyetlerin maliyetlerini ise maliyet öznelerine yükleyen, maliyet sürücüleri ve faaliyetler arasında neden sonuç ilişkisi kurabilen bir yaklaşım olarak tanımlamışlardır.

FTM sistemi yönetim muhasebesinde mamul ve/veya hizmetlerin maliyetlerinin belirlenmesinde kullanılabilecek bir yöntemdir. Maliyetler, yöneticilerin maliyetini belirlemek istediği her türden mamul/hizmet/müşteri gibi maliyet öznelerine yüklenmektedir. FTM sisteminin kullanılması, kaynak tüketiminin ve faaliyetlerin maliyetlerinin optimize edilmesinde yöneticilerin ihtiyaç duyacağı bilgileri sağlayacaktır. (Reddy vd. 2012: 1062)

Geleneksel hacim tabanlı maliyetleme sistemleri, kaynakların planlanması kararlarında faydalı olmamaları ve genel üretim maliyetlerinin mamul ve hizmetlere yüklenmesinde hacim tabanlı olmayan maliyet sürücülerini göz ardı etmeleri sebebiyle eleştirilmektedirler. Buna ek olarak, "maliyet-hacim-kar analizi" gibi geleneksel maliyet muhasebesi teknikleri, kayda değer oranda sermaye yatırımı gerektiren mamuller için yapılacak yatırımların firsat maliyetini göz ardı etmekte ve işletmenin sermaye maliyetinden daha düşük oranda getirisi olan mamullerin kabul edilmesine sebep olabilmektedir. (Tsai vd. 2011:7276)

FTM sistemini geliştirmek için gerekli olan aşamalar aşağıdaki gibidir : (Mowen ve Hansen, 2011: 146)

- $\quad$ İşletme çalışanlarının eğitilmesi,

- İşletmede gerçekleştirilen faaliyetlerin tanımlanması ve sınıflandırılması,

- $\quad$ Faaliyet maliyet havuzlarının belirlenmesi ve faaliyetleri gerçekleştirmek için kullanılan kaynakların maliyetlerinin, faaliyet maliyet havuzlarına doğrudan ya da bir yükleme anahtarı (kaynak sürücüsü) kullanılarak dolaylı olarak dağıtılması,

- Her bir faaliyet çeşidi için uygun bir yükleme anahtarı (faaliyet sürücüsü) tanımlanması ve maliyetlerin, faaliyet maliyet havuzlarından mamullere ya da diğer maliyet öznelerine uygun bir maliyet sürücüsü kullanılarak dağıtılması. 
FTM sistemi, işletmelerde meydana gelen genel üretim maliyetlerinin maliyet öznelerine yüklenmesinde faaliyet tabanlı maliyet sürücüleri kullanması bakımından geleneksel hacim tabanlı maliyetleme sistemlerinden farklılık göstermektedir. Gelişen ve değişen üretim ortamlarında faaliyet gösteren işletmelerin üretmekte oldukları mamul ve hizmetlerin sahip olduğu geniş yelpazeyi ve kaynak tüketim seviyelerini maliyetlere yansitabilen ve bu anlamda işletme yöneticilerini stratejik yönetim, maliyet yönetimi ve performans ölçümleme aşamalarında destekleyen FTM sisteminin anahtar kavramları Tablo 1'de özetlenmektedir:

Tablo 1. FTM Sisteminin Anahtar Kavramları

\begin{tabular}{|c|c|c|}
\hline \multicolumn{3}{|c|}{ FTM Sisteminin Anahtar Kavramları } \\
\hline No & Kavram & Tanım \\
\hline 1 & Kapasite & Faaliyetleri gerçekleştirme gücü. \\
\hline 2 & Kaynak & $\begin{array}{c}\text { Faaliyetlerin gerçekleştirilmesi esnasında tüketilen } \\
\text { ekonomik faktörler. }\end{array}$ \\
\hline 3 & Faaliyet & Çalışma esnasında gerçekleşen süreçler ve işlemler. \\
\hline 4 & Faaliyet Merkezi & İlişkili faaliyetler grubu. \\
\hline 5 & Kaynak Sürücüsü & $\begin{array}{l}\text { Kaynak maliyetlerinin faaliyetlere dağıtılması } \\
\text { aşamasında (1. Aşama) kullanılan faktörler. }\end{array}$ \\
\hline 6 & Faaliyet Maliyet Havuzu & Faaliyet ile ilişkilendirilen toplam maliyet. \\
\hline 7 & Faaliyet Sürücüsü & $\begin{array}{c}\text { Faaliyet maliyetlerinin maliyet öznelerine } \\
\text { yüklenmesi aşamasında (2. Aşama) kullanılan } \\
\text { faktörler. }\end{array}$ \\
\hline 8 & Maliyet Öznesi & $\begin{array}{l}\text { Faaliyetlerin gerçekleştirilmesinin esas nedeni. } \\
\text { (Mamul, hizmet, müşteri, vb.) }\end{array}$ \\
\hline
\end{tabular}

Kaynak: Onat, 2014: 151.

\section{1. $\quad$ FTM Sistemine Yöneltilen Eleștiriler}

Geleneksel hacim tabanlı maliyetleme sistemine alternatif olarak geliştirilen FTM sistemi teoride oldukça faydalı olsa da uygulamada bir takım güçlüklere neden olmaktadır. FTM sisteminde işletme çalışanları ile yapılan mülakat görüşmeleri ve araştırma süreci zaman alıcı ve maliyetlidir. Mülakat yolu ile çalışanlardan elde edilen bilgiler sübjektif olmaktadır. Çalışanlarla yapılan mülakatlarda elde edilen faaliyet bilgileri yoruma açıktır ve bilgilerin toplanması fazla zaman almaktadır. Bununla birlikte çalışanlar anketleri yanıtlarken boşa geçen süreleri hesaba katmayarak kullanılmayan kapasiteyi göz ardı etmekte ve hatalı maliyet hesaplamalarına yol açabilmektedir. (Namazi, 2016: 458; Yaşar, 2017: 206) Bunun yanı sıra, FTM sisteminin ürettiği bilgiler lokal özellik göstermektedir ve yöneticilere işletmelerin bütününe yönelik bir bakış açısı sağlamamaktadır. (Erkuş vd. 2014: 24)

FTM sistemi geleneksel hacim tabanlı maliyetleme sisteminin eleştirilen bir özelliği olan keyfi dağıtım anahtarı kullanılmasının önüne geçmemektedir. İşletmelerde ortaya çıkan bütün maliyetler maliyet özneleri ile doğrudan veya endirekt olarak ilişkilendirilemeyebilmektedir. Maliyet özneleri ile ilişkilendirilemeyen maliyetlerin mamul ve hizmetlere yüklenmesinde geleneksel hacim tabanlı maliyetleme sistemlerinde kullanılan 
yöntemler FTM sisteminde de kullanılacağı için keyfi dağıtım anahtarı kullanımı kaçınılmaz olacaktır. Bununla birlikte, FTM sistemini uygularken işletmelerde kolay ölçümlenebilen ve kullanıma hazır durumda bulunan maliyet sürücülerine sahip olunamadığından sistemin kurulum maliyetleri yükselmektedir. (Erdoğan ve Saban, 2010: 547)

\section{ZAMAN SÜRÜCÜLÜ FAALIYYET TABANLI MALIYYTLEME SÍSTEMİ (ZSFTM)}

FTM sisteminin uygulanmasında özellikle işletmelerin mevcut bilgi sistemleri yeni sistem için gerekli bilgileri üretemiyor ise oldukça maliyetli olmaktadır. (Kim vd. 2016: 288) Gerçekleştirilen bir anket çalışmasına göre FTM sistemi en çok uygulanan yönetim araçları içerisinde 1995 yılında 11. Surada iken 2002 yılında 22. Siraya gerilemiştir. (Stratton vd. 2009: 31) FTM yönteminin daha önce de belirtilen eksiklikleri nedeni ile işletmeler tarafindan uygulamasından vazgeçilmesi sonucunda, sistemin faydalarını yitirmeden kaynak maliyetlerini doğrudan maliyet özneleri ile ilişkilendiren kolaylaştırılmış bir FTM sistemi olarak Kaplan ve Anderson "Zaman Sürücülü Faaliyet Tabanlı Maliyetleme" (ZSFTM) sistemini geliştirmişlerdir. (Dalcı vd. 2010: 611; Demeere vd. 2009: 296)

ZSFTM sistemi, tek bir maliyet sürücüsü olarak "zamanı" dikkate alan; işletmelerde gerçekleştirilen faaliyetler ile ilişkili standart süreleri geleneksel FTM sistemindeki mülakat süreçleri yerine doğrudan gözlem yaparak elde etme olanağı sağlayan; işletmelerin sahip oldukları kaynak gruplarının normal kapasitesini kullanarak maliyet hesaplamaları yapan ve bu sayede geleneksel FTM sistemine göre daha basit şekilde ve daha doğru maliyet hesaplamaları yapabilen bir maliyetleme yaklaşımıdır. (Yükçü ve Gönen, 2009: 20-21)

ZSFTM sisteminin sahip olduğu en önemli yenilik, faaliyet maliyetlerinin hesaplanmasına zaman değişkenini de dahil etmesi olmaktadır. (Todorovic, 2016: 204) ZSFTM sisteminde yöneticiler geleneksel FTM sisteminin ilk aşamasını oluşturan kaynakların faaliyetlere dağıtılması aşamasını ortadan kaldırarak bunun yerine birden fazla farklı zaman sürücüsünün bir fonksiyonu olarak ifade edilen ve bir faaliyetin gerçekleşmesi için ihtiyaç duyulan zamanı belirleyen zaman denklemlerini kullanarak kaynak gruplarının maliyetlerini doğrudan maliyet özneleri ile ilişkilendirmektedir. (Cengiz, 2011: 34)

ZSFTM sisteminin uygulama aşamaları aşağıdaki şekilde gerçekleşmektedir: (Özyürek ve Dinç, 2014: 351) belirlenmesi,

- İşletmenin kaynak gruplarının ve bu kaynakların kullanıldığı faaliyetlerin

- $\quad$ İşletmenin kaynak gruplarına ait maliyetlerin belirlenmesi,

- $\quad$ İşletmenin her kaynak grubu için normal kapasitelerin tahmin edilmesi,

- İşletmenin her kaynak grubu için kapasite maliyet oranının (birim zaman maliyeti) hesaplanmas1, belirlenmesi,

- İşletmede gerçekleştirilen faaliyetler için gerekli olan birim sürelerin 
- İşletmenin kaynak gruplarına ait kapasite maliyet oranları ile her kaynak grubu için gerekli olan toplam süre çarpılarak kaynak gruplarına atanan toplam maliyetlerin tespit edilmesi.

Zaman sürücülü FTM sisteminin geleneksel FTM sistemine kıyasla sağladığ1 avantajlar kısaca şu şekilde özetlenebilmektedir: (Özyürek ve Dinç, 2014: 350)

- $\quad$ ZSFTM sistemi daha az maliyetli, uygulaması ve güncellemesi kolay, hızlı ve sürdürülebilir bir maliyetleme sistemidir.

- $\quad$ ZSFTM sistemi işletmelerin kullanmakta oldukları Kurumsal Kaynak Planlaması (ERP) ile Müşteri İlişkileri Yönetimi (CRP) ile uyumluluk sağlamaktadır.

- $\quad$ ZSFTM sisteminde özellikli siparişler, süreçler, tedarikçiler ve müşteriler için nitelikli özelliklerin dahil edilmesi mümkün olmaktadır.

- $\quad$ ZSFTM sistemi işletmelerde gerçekleşen süreçlerin verimliliği ve bu süreçlerin tüketmekte oldukları kaynakların yönetiminde şeffaflık sağlamaktadır. sağlamaktadır.

- $\quad$ ZSFTM sistemi geleceğe yönelik kaynak planlaması yapılmasına olanak

\section{X TRAVERTEN A.Ş. İŞLETMESINNDE ZSFTM UYGULAMASI}

\subsection{Uygulama Yapılacak Traverten İşletmesi Hakkında Bilgiler}

Çalışmanın konusunu oluşturan modern maliyet sistemlerinin uygulandığı traverten sanayi işletmesi, 2007 yılından beri Denizli'de faaliyet göstermektedir. İşletme Denizli'de sektörün önde gelen traverten sanayi işletmelerinden biridir. İşletme yönetimi, çalışmaya katkıda bulunmayı ancak işletme adının ve bilgilerinin gizli tutulması koşulu ile kabul etmiştir. $\mathrm{Bu}$ sebeple örnek işletmeden "X Traverten Sanayi ve Ticaret A.Ş." olarak bahsedilecektir.

X Traverten San. Ve Tic. A.Ş. işletmesi 175 kişilik çalı̧an kadrosuna sahiptir. Çalışanların 10'u idari kadroda yer alırken, 165 kişi üretimde görev almaktadır. İşletme $17.000 \mathrm{~m} 2$ 'si kapalı alan olmak üzere, toplam $32.000 \mathrm{~m} 2$ alana kurulmuştur. İşletme fabrikasında satış-pazarlama, genel yönetim, üretim ve sevkiyat bölümü faaliyetleri gerçekleştirilmektedir. Muhasebe ve finansman faaliyetleri dışarıdan sağlanmaktadır. Üretiminin büyük bir kısmını ihracata yönelik gerçekleştiren X Traverten San. Tic. A.Ş. işletmesi başta $\mathrm{ABD}$ olmak üzere, Avustralya, Kanada, Almanya ve Fransa'da bulunan müşterilerine işlenmiş traverten satışı gerçekleştirmektedir.

İşletmede müşterinin siparişi doğrultusunda temin edilen traverten blokları fabrikaya getirildikten sonra, siparişin özelliğine göre st veya katrak makinelerinde strip veya plaka haline getirilmek amacı ile kesilmekte ve daha sonra sipariş ölçüsüne göre ebatlama işleminden geçmektedir. İşletmede üretimi gerçekleşip satılan mamuller $3 \mathrm{~cm}, 5 \mathrm{~cm}$ ve $1.2 \mathrm{~cm}$ kalınlığında ebatlanmaktadır. Ebatlanmış traverten stripleri, bu işlemden sonra siparişin niteliğine bağlı olarak silim makinelerinde cilalama, honlama, eskitme, brush, dolgulu honlama, bulnoz gibi işlemlerden geçmektedir. İşletmenin hitap ettiği müşteri kitlesi en fazla eskitme tekniğine göre üretilen traverten mamulleri satın almayı tercih etmektedir. Silim makinelerinde işlem gören traverten stripleri bu aşamadan sonra seleksiyon bölümüne gelmektedir. Seleksiyon bölümünde kalite kontrol işlemleri gerçekleşmektedir. Üretilen 
traverten striplerinin istenen kalitede olup olmadığı kontrol edildikten sonra varsa düşük kalite stripler tekrar işlemden geçirilip düzeltilmektedir. Siparişi verilen mamullerin üretim aşamaları tamamlandıktan sonra sıra travertenlerin sevkiyatına gelmektedir. Mamuller paletlere yüklenip kasaların içerisine yerleştirilmektedir. Mamulleri taşımacılık esnasında nemden ve kalitelerini bozabilecek diğer etkenlerden korumak amacı ile lashing işlemi gerçekleştirilmektedir. Bu sayede mamuller uzak mesafelerdeki müşterilere gönderilirken herhangi bir zarar görmemeleri sağlanmaktadır. Kasaların üzerlerine hazırlanan etiketler çakılıp mamuller sevke hazır hale getirilmektedir.

\subsection{Araştırmanın Amacı ve Yöntemi}

Çalışmanın amacı, ZSFTM yöntemini traverten sanayi sektöründe faaliyet gösteren bir örnek işletme üzerinde uygulayarak, ulaşılan maliyet bilgilerini değerlendirmek ve ZSFTM yönteminin işletmeye sağlamakta olduğu avantajları ve dezavantajları araştırmaktır. Bu çalışmanın temel hipotezi, ZSFTM sisteminin mermer işletmelerinde doğru ve anlamlı maliyet bilgisi üretmekte olduğudur.

Çalışmada olay çalışması yöntemi kullanılmıştır. X Traverten A.Ş. işletmesinde ortaya çıkan maliyetler ZSFTM yöntemi kullanılarak hesaplanmış ve seçilen mamullerin birim maliyetleri belirlenmiştir. Uygulamaya konu edilecek maliyet öznesi olarak, 6 adet traverten mermer çeşidi mümkün olduğu kadar üretim aşamaları birbirinden farklılık gösterecek şekilde ve işletmenin en fazla üretim ve satışını gerçekleştirmekte olduğu mamul çeşitlerinden seçilmiştir. Araştırma için gerekli olan bilgiler işletme çalışanları ile yapılan mülakatlar ve doğrudan yapılan gözlemler sonucunda elde edilmiştir.

\subsection{Traverten A.Ş. İşletmesine ZSFTM Sisteminin Uygulanması}

ZSFTM sisteminin X Traverten A.Ş. işletmesinde gerçekleştirilen uygulamasında geleneksel FTM sisteminden farklı olarak iki parametrenin bilinmesi gerekmektedir. Bu parametreler sırası ile, işletmenin kaynak gruplarının kapasitelerinin birim zaman maliyeti ve mamul seviyesinde kapasite tüketimi şeklinde olmaktadır. ZSFTM sistemi maliyet hesaplamalarında normal kapasite kullanılmaktadır. $\mathrm{Bu}$ bağlamda ZSFTM sistemi kullanılmayan kapasitenin maliyetini mamullere yüklememektedir.

\subsubsection{Genel Üretim Maliyetlerinin Belirlenmesi}

ZSFTM sistemi, geleneksel hacim tabanlı maliyet sistemi uygulamalarından genel üretim maliyetlerinin mamullere yüklenmesi aşamasında farklılık göstermektedir. ZSFTM uygulamalarının geleneksel maliyetleme sistemlerine kıyasla daha doğru maliyet bilgisi üretebilmesi için genel üretim maliyetleri ile maliyet özneleri arasında neden-sonuç ilişkisi kurabilmesi ve dağıtım anahtarlarının bu şekilde belirlenmesi gerekmektedir. Bu bölümde uygulamanın gerçekleştirildiği X Traverten A.Ş. işletmesinin mevcut hesap planı ZSFTM uygulamasına uygun hale getirilecek şekilde incelenerek genel üretim maliyetleri sinıflandırılmaktadır. Tablo 2'de X Traverten A.Ş.'nin genel üretim maliyetlerinin sınıflandırılması görülmektedir. 
Tablo 2. Genel Üretim Maliyetlerinin Sınıflandırılmas1

\begin{tabular}{|c|c|c|c|c|}
\hline \multicolumn{2}{|c|}{ Genel Üretim Maliyetleri } & Tutar (TL) & Toplam Tutar (TL) & Maliyet Payı (\%) \\
\hline \multirow[b]{3}{*}{$\begin{array}{l}\text { Endirekt Madde ve } \\
\text { Malzeme }\end{array}$} & $\begin{array}{l}\text { Kesici Malzemeler } \\
\text { (Elmas, abresiv, vb.) }\end{array}$ & $719.520,27$ & \multirow[b]{3}{*}{ 1.214.211,52 } & \multirow[b]{3}{*}{20,01} \\
\hline & Boya ve Kimyasallar & $101.682,74$ & & \\
\hline & Diğer & $393.008,51$ & & \\
\hline Endirekt İşçilik & Endirekt Ücretler & $1.032 .300,89$ & 1.032.300,89 & $\mathbf{1 7 , 0 1}$ \\
\hline \multirow[b]{3}{*}{ Amortisman } & Makine ve Cihazlar & $152.121,65$ & \multirow[b]{3}{*}{$184.165,41$} & \multirow[b]{3}{*}{3,04} \\
\hline & Bina & $23.727,15$ & & \\
\hline & Demirbaş & $8.316,61$ & & \\
\hline \multirow{6}{*}{ Enerji ve Su Giderleri } & Elektrik 1 & $1.220 .049,46$ & \multirow{6}{*}{$1.403 .682,27$} & \multirow{6}{*}{23,13} \\
\hline & Elektrik 2 & $5.563,73$ & & \\
\hline & Su ve İlaç & $25.207,12$ & & \\
\hline & $\mathrm{Su}$ & $2.232,68$ & & \\
\hline & Motorin 1 & $109.959,37$ & & \\
\hline & Motorin 2 & $40.669,91$ & & \\
\hline \multirow{10}{*}{$\begin{array}{l}\text { Üretim ile İlgili Diğer } \\
\text { Giderler }\end{array}$} & $\begin{array}{c}\text { Makine Bakım } \\
\text { Onarım Giderleri }\end{array}$ & $833.249,92$ & \multirow{10}{*}{ 2.233.261,10 } & \multirow{10}{*}{36,81} \\
\hline & $\begin{array}{l}\text { Personel Servis } \\
\text { Giderleri }\end{array}$ & $281.285,73$ & & \\
\hline & $\begin{array}{l}\text { Personel Yemek } \\
\text { Giderleri }\end{array}$ & $171.309,89$ & & \\
\hline & $\begin{array}{l}\text { Araç Bakım Onarım } \\
\text { Giderleri }\end{array}$ & $79.666,62$ & & \\
\hline & Kargo Giderleri & $1.985,35$ & & \\
\hline & Haberleşme Giderleri & $5.914,73$ & & \\
\hline & Sigorta Giderleri & $111.908,18$ & & \\
\hline & Mutfak Giderleri & $13.928,29$ & & \\
\hline & Kirtasiye Giderleri & $6.641,72$ & & \\
\hline & Diğer Giderler & $727.370,67$ & & \\
\hline TOPLAM & & 6.067.621,19 & 6.067.621,19 & 100 \\
\hline
\end{tabular}

X Traverten A.Ş. işletmesi bünyesindeki kaynak grupları aşağıdaki şekildedir:

- $\quad$ Satın Alma ve Üretim Planlama Kaynak Grubu

- $\quad$ ST Kesim Kaynak Grubu

- $\quad$ Yarma Kaynak Grubu

- $\quad$ Tirmik Ebatlama Kaynak Grubu

- $\quad$ Silim Kaynak Grubu

- $\quad$ Eskitme Kaynak Grubu

- $\quad$ Seleksiyon Kaynak Grubu

- $\quad$ Depo ve Sevkiyat Kaynak Grubu

- $\quad$ Satış ve Pazarlama Kaynak Grubu

- $\quad$ Genel Yönetim Kaynak Grubu

X Traverten A.Ş. işletmesinde kaynak grupları oluşturulduktan sonra daha önceden belirlenen genel üretim maliyetlerinin uygun bir maliyet sürücüsü (1.aşama kaynak sürücüsü) aracılığı ile kaynak gruplarına dağıtım seviyeleri belirlenmektedir. Tablo 3'te maliyet ve kaynak grubu ilişkisi gösterilmektedir. Bu aşamada dağıtım seviyeleri belirlenirken mümkün olduğunca maliyet ve kaynak grubu arasındaki tüketim ilişkisini ortaya koyabilecek mantıklı 
maliyet sürücüleri belirlenmektedir. Örneğin, fabrika elektrik maliyetlerinin kaynak gruplar1 ile ilişkilendirilmesinde maliyet sürücüsü olarak makine saatleri kullanılmakta iken, personel yemek ve servis maliyetleri personel sayısı doğrultusunda kaynak grupları ile ilişkilendirilmektedir. Genel üretim maliyetlerinin kaynak gruplarına dağıtılmasına ilişkin hesaplamalar Tablo 4 ve Tablo 5 'te gösterilmektedir. Burada belirtilmesi gereken bir diğer önemli nokta ise, satış ve pazarlama kaynak grubu maliyeti olan 88.306,77 TL'nin üretimle doğrudan ilişkili olmaması sebebi ile mamul maliyetleri hesaplamalarında göz ardı edilecek olmasidir.

\subsubsection{ZSFTM Sisteminde Kaynak Gruplarının Maliyet Yükleme Oranlarının ve Faaliyetlerin Kapasite Tüketimlerinin Belirlenmesi}

Kaynak gruplarının birim kapasite maliyetleri hesaplandıktan sonra faaliyet havuzlarında gerçekleştirilen faaliyetlerin gerçekleşme süreleri hesaplanmaktadır. Bu süreler gözlem yolu ile kolaylıkla belirlenebilmektedir. Her bir faaliyetin gerçekleşme süresi ile ilgili faaliyetin zaman sürücüsü miktarı çarpılarak ilgili faaliyet için harcanan toplam zaman (kullanılan kapasite) bulunabilmektedir. Hesaplanan toplam zaman ile birim kapasite maliyeti çarpıldığında her bir faaliyetin toplam maliyeti (kullanılan kapasite maliyeti) hesaplanmaktadır. Faaliyet havuzlarının normal kapasitelerinden kullanılan kapasiteleri çıkarılarak atıl kapasite bilgisine ulaşılmaktadır. Elde edilen atıl kapasite süresi ve maliyetleri normal kapasiteye bölünerek atıl kapasite oranları hesaplanmaktadır. Satın alma ve üretim planlama kaynak grubuna ilişkin atıl kapasite maliyetleri Tablo 7'de gösterilmektedir. Örneğin, satın alma ve üretim planlama kaynak grubunun alt faaliyetlerinden biri olan üretim emri ve üretim raporlarının hazırlanması faaliyetini gerçekleştirmek için her bir üretim emri doğrultusunda 0,72 saat harcanmaktadır. Satın alma ve üretim planlama kaynak grubunun birim zaman maliyeti 29,91 TL'dir. Bu faaliyet için zaman sürücüsü olarak üretim emri sayıs1 dikkate alınmaktadır. Bir yıllık toplam hazırlanan üretim emri sayıs 5.168 adettir. $\mathrm{Bu}$ bilgilere göre, üretim emri ve raporlarının hazırlanması faaliyetinin birim faaliyet zamanı 0,72 saat ve birim maliyet yükleme oranı 21,54 (0,72 saat x 29,91 TL) şeklinde hesaplanmaktadır. $\mathrm{Bu}$ faaliyetin gerçekleşmesi için harcanan toplam zaman ise 3.720,96 saattir. (5.168 adet x 0,72 saat) Buna göre faaliyetin toplam maliyeti 111.293,91 TL (3.720,96 saat x 29,91 TL) olarak bulunmaktadir. 
(82): $1-20$

Tablo 3. X Traverten A.Ş. Maliyet - Kaynak Grubu İlişkisi

\begin{tabular}{|c|c|c|c|c|c|c|c|c|c|c|c|c|}
\hline \multirow{2}{*}{\multicolumn{2}{|c|}{ Maliyetler }} & \multirow{3}{*}{$\begin{array}{c}\text { Yükleme } \\
\text { Ölçüsü } \\
\text { Belirlenen } \\
\text { Oranlar }\end{array}$} & \multicolumn{10}{|c|}{ Kaynak Grubu } \\
\hline & & & $\begin{array}{l}\text { Satın } \\
\text { Alma }\end{array}$ & $\begin{array}{c}\text { ST } \\
\text { Kesim }\end{array}$ & Yarma & $\begin{array}{c}\text { Tirmik } \\
\text { Ebatlama }\end{array}$ & Silim & Eskitme & Seleksiyon & $\begin{array}{c}\text { Depo } \\
\text { Ve }\end{array}$ & $\begin{array}{l}\text { Satış } \\
\text { Ve }\end{array}$ & $\begin{array}{c}\text { Genel } \\
\text { Yönetim }\end{array}$ \\
\hline \multirow{3}{*}{$\begin{array}{l}\text { Endirekt } \\
\text { Madde ve } \\
\text { Malzeme }\end{array}$} & $\begin{array}{l}\text { Kesici Malz. } \\
\text { (Elmas, } \\
\text { abresiv, vb.) }\end{array}$ & & & 0,11 & 0,13 & 0,05 & 0,71 & & & & & \\
\hline & $\begin{array}{c}\text { Boya ve } \\
\text { Kimyasallar }\end{array}$ & $\begin{array}{c}\text { Belirlenen } \\
\text { Oranlar }\end{array}$ & & 0,14 & 0,18 & 0,07 & 0,49 & 0,12 & & & & \\
\hline & Diğer & $\begin{array}{c}\text { Belirlenen } \\
\text { Oranlar }\end{array}$ & & 0,12 & 0,14 & 0,10 & 0,18 & 0,16 & 0,18 & 0,12 & & \\
\hline Endirekt İşçilik & $\begin{array}{l}\text { Endirekt } \\
\text { Ücretler }\end{array}$ & $\begin{array}{c}\text { Belirlenen } \\
\text { Tutarlar }\end{array}$ & $\mathrm{X}$ & $\mathrm{X}$ & $\mathrm{X}$ & $\mathrm{X}$ & $\mathrm{X}$ & $\mathrm{X}$ & $\mathrm{X}$ & $\mathrm{X}$ & $\mathrm{X}$ & $\mathrm{X}$ \\
\hline \multirow{3}{*}{ Amortisman } & $\begin{array}{c}\text { Makine ve } \\
\text { Cihazlar }\end{array}$ & $\begin{array}{c}\text { Belirlenen } \\
\text { Tutarlar }\end{array}$ & & $\mathrm{X}$ & $\mathrm{X}$ & $\mathrm{X}$ & $\mathrm{X}$ & $\mathrm{X}$ & $\mathrm{X}$ & $\mathrm{X}$ & & \\
\hline & Bina & $\begin{array}{c}\text { Belirlenen } \\
\text { Alanlar }\end{array}$ & 0,01 & 0,14 & 0,08 & 0,11 & 0,19 & 0,10 & 0,08 & 0,26 & 0,01 & 0,02 \\
\hline & Demirbaş & $\begin{array}{c}\text { Belirlenen } \\
\text { Oranlar }\end{array}$ & 0,09 & & & & & & & 0,12 & 0,34 & 0,45 \\
\hline \multirow{7}{*}{$\begin{array}{c}\text { Enerji ve } \mathrm{Su} \\
\text { Giderleri }\end{array}$} & Elektrik 1 & $\begin{array}{l}\text { Makine } \\
\text { Saatleri }\end{array}$ & & 0,25 & 0,08 & 0,11 & 0,32 & 0,13 & 0,03 & 0,08 & & \\
\hline & Elektrik 2 & $\begin{array}{c}\text { Belirlenen } \\
\text { Alanlar }\end{array}$ & 0,23 & & & & & & & & 0,36 & 0,41 \\
\hline & Su ve İlaç & $\begin{array}{c}\text { Belirlenen } \\
\text { Oranlar }\end{array}$ & & 0,54 & 0,15 & 0,02 & 0,12 & 0,14 & 0,03 & & & \\
\hline & $\mathrm{Su}$ & $\begin{array}{c}\text { Belirlenen } \\
\text { Oranlar }\end{array}$ & 0,38 & & & & & & & 0,08 & 0,20 & 0,34 \\
\hline & Motorin 1 & $\begin{array}{l}\text { Giderin } \\
\text { Tümü }\end{array}$ & & & & & & & & $\mathrm{X}$ & & \\
\hline & Motorin 2 & $\begin{array}{c}\text { Belirlenen } \\
\text { Tutarlar }\end{array}$ & $\mathrm{X}$ & & & & & & & & $\mathrm{X}$ & $\mathrm{X}$ \\
\hline & $\begin{array}{l}\text { Makine } \\
\text { Bakım }\end{array}$ & $\begin{array}{l}\text { Makine } \\
\text { Adedi }\end{array}$ & & $\mathrm{X}$ & $\mathrm{X}$ & $\mathrm{X}$ & $\mathrm{X}$ & $\mathrm{X}$ & $\mathrm{X}$ & $\mathrm{X}$ & & \\
\hline
\end{tabular}


Muhasebe ve Finansman Dergisi - Nisan/2019

(82): $1-20$

\begin{tabular}{|c|c|c|c|c|c|c|c|c|c|c|c|c|}
\hline \multirow{10}{*}{$\begin{array}{l}\text { Üretim ile İlgili } \\
\text { Diğer Giderler }\end{array}$} & $\begin{array}{c}\text { Onarım } \\
\text { Giderleri }\end{array}$ & & & & & & & & & & & \\
\hline & $\begin{array}{l}\text { Personel } \\
\text { Servis } \\
\text { Giderleri }\end{array}$ & $\begin{array}{c}\text { Personel } \\
\text { Sayıs1 }\end{array}$ & 0,02 & 0,10 & 0,14 & 0,16 & 0,16 & 0,16 & 0,23 & 0,005 & 0,01 & 0,015 \\
\hline & $\begin{array}{c}\text { Personel } \\
\text { Yemek } \\
\text { Giderleri }\end{array}$ & $\begin{array}{c}\text { Personel } \\
\text { Sayıs1 }\end{array}$ & 0,02 & 0,10 & 0,14 & 0,16 & 0,16 & 0,16 & 0,23 & 0,005 & 0,01 & 0,015 \\
\hline & $\begin{array}{c}\text { Araç Bakım } \\
\text { Onarım } \\
\text { Giderleri }\end{array}$ & Araç Sayısı & $X$ & & & & & & & & $\mathrm{X}$ & $\mathrm{X}$ \\
\hline & $\begin{array}{c}\text { Kargo } \\
\text { Giderleri } \\
\end{array}$ & $\begin{array}{c}\text { Gönderi } \\
\text { Sayıs1 }\end{array}$ & $X$ & & & & & & & & $\mathrm{X}$ & $\mathrm{X}$ \\
\hline & $\begin{array}{c}\text { Haberleşme } \\
\text { Giderleri }\end{array}$ & $\begin{array}{c}\text { Belirlenen } \\
\text { Tutarlar }\end{array}$ & $X$ & & & & & & & & $\mathrm{X}$ & $\mathrm{X}$ \\
\hline & $\begin{array}{c}\text { Sigorta } \\
\text { Giderleri }\end{array}$ & $\begin{array}{c}\text { Giderin } \\
\text { Tümü }\end{array}$ & & & & & & & & & & $\mathrm{X}$ \\
\hline & $\begin{array}{c}\text { Mutfak } \\
\text { Giderleri }\end{array}$ & $\begin{array}{c}\text { Personel } \\
\text { Sayis1 }\end{array}$ & 0,40 & & & & & & & 0,10 & 0,20 & 0,30 \\
\hline & $\begin{array}{l}\text { Kirtasiye } \\
\text { Giderleri }\end{array}$ & $\begin{array}{c}\text { Belirlenen } \\
\text { Tutarlar }\end{array}$ & $X$ & & & & & & & & $\mathrm{X}$ & $\mathrm{X}$ \\
\hline & $\begin{array}{c}\text { Diğer } \\
\text { Giderler }\end{array}$ & $\begin{array}{c}\text { Belirlenen } \\
\text { Tutarlar }\end{array}$ & $X$ & $X$ & $\mathrm{X}$ & $\mathrm{X}$ & $\mathrm{X}$ & $\mathrm{X}$ & $\mathrm{X}$ & $\mathrm{X}$ & & $\mathrm{X}$ \\
\hline
\end{tabular}


(82): $1-20$

Tablo 4. Genel Üretim Maliyetlerinin Kaynak Gruplarında Biriktirilmesi

\begin{tabular}{|c|c|c|c|c|c|c|c|}
\hline \multirow[b]{2}{*}{ Kaynak Grupları } & \multicolumn{5}{|c|}{ Maliyetler } & \multirow[t]{2}{*}{ Toplam } & \multirow[t]{2}{*}{ Maliyet Payı } \\
\hline & $\begin{array}{l}\text { Endirekt Madde } \\
\text { ve Malzeme } \\
\text { Maliyetleri }\end{array}$ & $\begin{array}{c}\text { Endirekt İşçilik } \\
\text { Maliyetleri }\end{array}$ & $\begin{array}{c}\text { Amortisman } \\
\text { Maliyetleri }\end{array}$ & $\begin{array}{l}\text { Enerji ve Su } \\
\text { Maliyetleri }\end{array}$ & $\begin{array}{l}\text { Üretim ile İlgili Diğer } \\
\text { Maliyetler }\end{array}$ & & \\
\hline $\begin{array}{c}\text { Satın Alma ve Üretim } \\
\text { Planlama }\end{array}$ & & $110.513,40$ & 985,76 & $13.748,05$ & $28.319,61$ & $153.566,82$ & $\mathbf{0 , 0 3}$ \\
\hline ST Kesim & $140.543,84$ & $34.813,70$ & $64.881,43$ & $318.624,22$ & $239.024,04$ & $\mathbf{7 9 7 . 8 8 7 , 2 3}$ & $\mathbf{0 , 1 3}$ \\
\hline Yarma & $166.861,73$ & $48.739,16$ & $12.796,21$ & $101.385,03$ & $211.656,23$ & $541.438,36$ & $\mathbf{0 , 0 9}$ \\
\hline Tirmik Ebatlama & $82.394,65$ & $55.701,90$ & $14.707,03$ & $134.709,58$ & $196.109,90$ & 483.623,06 & $\mathbf{0 , 0 8}$ \\
\hline Silim & $631.425,46$ & $59.183,26$ & $53.781,88$ & $393.440,68$ & $384.673,44$ & $1.522 .504,72$ & 0,25 \\
\hline Eskitme & $75.083,29$ & $62.664,63$ & $11.921,42$ & $162.135,43$ & $235.607,77$ & $547.412,54$ & 0,09 \\
\hline Seleksiyon & $70.741,53$ & $87.034,20$ & $5.239,47$ & $37.357,69$ & $253.865,90$ & $454.238,79$ & $\mathbf{0 , 0 7}$ \\
\hline Depo ve Sevkiyat & $47.161,02$ & $26.379,12$ & $12.570,28$ & $210.646,92$ & $128.548,00$ & $425.305,34$ & $\mathbf{0 , 0 7}$ \\
\hline Satış ve Pazarlama & & $45.221,28$ & $3.064,92$ & $8.259,48$ & $18.967,52$ & $75.513,20$ & $\mathbf{0 , 0 1}$ \\
\hline Genel Yönetim & & $502.050,24$ & $4.217,01$ & $23.375,19$ & $536.488,69$ & $1.066 .131,13$ & $\mathbf{0 , 1 8}$ \\
\hline Toplam & 1.214.211,52 & 1.032.300,89 & $184.165,41$ & $1.403 .682,27$ & $2.233 .261,10$ & 6.067.621,19 & 1 \\
\hline
\end{tabular}

Tablo 5. Genel Yönetim Kaynak Grubu Maliyetlerinin Diğer Kaynak Gruplarına Dağıtılmas1

\begin{tabular}{|c|c|c|c|c|c|c|c|c|c|}
\hline $\begin{array}{c}\text { Genel Yönetim } \\
\text { Maliyetleri }\end{array}$ & $\begin{array}{l}\text { Satın Alma ve } \\
\text { Üretim } \\
\text { Planlama }\end{array}$ & ST Kesim & Yarma & Tirmik Ebatlama & Silim & Eskitme & Seleksiyon & $\begin{array}{c}\text { Depo } \\
\text { ve Sevkiyat }\end{array}$ & $\begin{array}{c}\text { Satış } \\
\text { ve } \\
\text { Pazarlama }\end{array}$ \\
\hline $1.066 .131,13$ & $153.566,82$ & $797.887,23$ & $541.438,36$ & $483.623,06$ & $1.522 .504,72$ & $\mathbf{5 4 7 . 4 1 2 , 5 4}$ & $454.238,79$ & $425.305,34$ & $75.513,20$ \\
\hline Yükleme Oranı & 0,024 & 0,134 & 0,102 & 0,088 & 0,314 & 0,098 & 0,154 & 0,074 & 0,012 \\
\hline Yüklenecek Tutar & $25.587,16$ & $142.861,57$ & $108.745,38$ & $93.819,54$ & $334.765,17$ & $104.480,85$ & $164.184,19$ & $78.893,70$ & $12.793,57$ \\
\hline TOPLAM & $179.153,98$ & $940.748,80$ & $650.183,74$ & $577.442,60$ & $1.857 .269,89$ & $651.893,39$ & $618.422,98$ & $504.199,04$ & $88.306,77$ \\
\hline
\end{tabular}


Tablo 6. ZSFTM Sisteminde Kaynak Gruplarının Normal Kapasitelerinin ve Birim Kapasite Maliyetlerinin Hesaplanması

\begin{tabular}{|c|c|c|c|c|c|c|c|c|}
\hline $\begin{array}{c}\text { Kaynak } \\
\text { Grubu }\end{array}$ & $\begin{array}{c}\text { Kaynak } \\
\text { Grubu } \\
\text { Maliyeti } \\
\text { (TL) }\end{array}$ & $\begin{array}{l}\text { Kapasite } \\
\text { Türü }\end{array}$ & $\begin{array}{c}\text { Faaliyeti } \\
\text { Gerçekleştiren } \\
\text { Aktif } \\
\text { Çalışan } \\
\text { Sayısı }\end{array}$ & $\begin{array}{c}\text { Birim } \\
\text { Çalışan } \\
\text { İçin } \\
\text { Yıllık } \\
\text { Çalışma } \\
\text { Zamanı } \\
\text { (Saat) }\end{array}$ & $\begin{array}{c}\text { Toplam } \\
\text { Yllık } \\
\text { Teorik } \\
\text { Kapasite } \\
\text { (Saat) }\end{array}$ & $\begin{array}{c}\text { Normal } \\
\text { Kapasite } \\
\text { Oranı }\end{array}$ & $\begin{array}{c}\text { Toplam } \\
\text { Yıllık } \\
\text { Normal } \\
\text { Kapasite }\end{array}$ & $\begin{array}{c}\text { Birim Kapasite Maliyeti } \\
\text { (TL/Saat) }\end{array}$ \\
\hline $\begin{array}{c}\text { Satın } \\
\text { Alma ve } \\
\text { Üretim } \\
\text { Planlama }\end{array}$ & $179.153,98$ & İnsan/Zaman & 3 & 2.496 & 7.488 & 80 & $5.990,40$ & 29,91 \\
\hline ST Kesim & $940.748,80$ & Makine/Zaman & 8 & 4.952 & 39.616 & 75 & 29.712 & 31,66 \\
\hline Yarma & $650.183,74$ & Makine/Zaman & 4 & 3.068 & 12.272 & 75 & 9.204 & 70,64 \\
\hline $\begin{array}{c}\text { Tirmik } \\
\text { Ebatlama }\end{array}$ & $577.442,60$ & Makine/Zaman & 6 & 5.042 & 30.252 & 75 & 22.689 & 25,45 \\
\hline Silim & $1.857 .269,89$ & Makine/Zaman & 9 & 4.868 & 43.812 & 75 & 32.859 & 56,52 \\
\hline Eskitme & $651.893,39$ & Makine/Zaman & 5 & 4.964 & 24.820 & 75 & 18.615 & 35,02 \\
\hline Seleksiyon & $618.422,98$ & İnsan/Zaman & 15 & 2.912 & 43.680 & 80 & 34.944 & 17,70 \\
\hline $\begin{array}{l}\text { Depo ve } \\
\text { Sevkiyat }\end{array}$ & $504.199,04$ & İnsan/Zaman & 2 & 2.496 & 4.992 & 80 & $3.993,60$ & 126,25 \\
\hline TOPLAM & $5.979 .314,42$ & & 52 & & 206.932 & & $158.007,00$ & \\
\hline
\end{tabular}

\subsubsection{ZSFTM Sisteminde Kaynak Gruplarının Maliyet Yükleme Oranlarının ve Faaliyetlerin Kapasite Tüketimlerinin Belirlenmesi}

Kaynak gruplarının birim kapasite maliyetleri hesaplandıktan sonra faaliyet havuzlarında gerçekleştirilen faaliyetlerin gerçekleşme süreleri hesaplanmaktadır. Bu süreler gözlem yolu ile kolaylıkla belirlenebilmektedir. Her bir faaliyetin gerçekleşme süresi ile ilgili faaliyetin zaman sürücüsü miktarı çarpılarak ilgili faaliyet için harcanan toplam zaman (kullanılan kapasite) bulunabilmektedir. Hesaplanan toplam zaman ile birim kapasite maliyeti çarpıldığında her bir faaliyetin toplam maliyeti (kullanılan kapasite maliyeti) hesaplanmaktadır. Faaliyet havuzlarının normal kapasitelerinden kullanılan kapasiteleri çıkarılarak atıl kapasite bilgisine ulaşılmaktadır. Elde edilen atıl kapasite süresi ve maliyetleri normal kapasiteye bölünerek atıl kapasite oranları hesaplanmaktadır. Satın alma ve üretim planlama kaynak grubuna ilişkin atıl kapasite maliyetleri Tablo 7'de gösterilmektedir. Örneğin, satın alma ve üretim planlama kaynak grubunun alt faaliyetlerinden biri olan üretim emri ve üretim raporlarının hazırlanması faaliyetini gerçekleştirmek için her bir üretim emri doğrultusunda 0,72 saat harcanmaktadır. Satın alma ve üretim planlama kaynak grubunun birim zaman maliyeti 29,91 TL'dir. Bu faaliyet için zaman sürücüsü olarak üretim emri sayısı dikkate alınmaktadır. Bir yıllık toplam hazırlanan üretim emri sayısı 5.168 adettir. $\mathrm{Bu}$ bilgilere göre, üretim emri ve raporlarının hazırlanması faaliyetinin birim faaliyet zamanı 0,72 saat ve birim maliyet yükleme oranı 21,54 (0,72 saat x 29,91 TL) şeklinde hesaplanmaktadır. 
$\mathrm{Bu}$ faaliyetin gerçekleşmesi için harcanan toplam zaman ise 3.720,96 saattir. (5.168 adet $\mathrm{x}$ 0,72 saat) Buna göre faaliyetin toplam maliyeti 111.293,91 TL (3.720,96 saat x 29,91 TL) olarak bulunmaktadır.

Tablo 7. Satın Alma ve Üretim Planlama Kaynak Grubu Faaliyetlerinin Gerçekleştirilmesi İçin İhtiyaç Duyulan Zaman ile Maliyet Yükleme Oranlarının Belirlenmesi

\begin{tabular}{|c|c|c|c|c|c|c|c|c|}
\hline $\begin{array}{c}\text { Kaynak } \\
\text { Grubu }\end{array}$ & Faaliyetler & $\begin{array}{l}\text { Birim } \\
\text { Faaliyet } \\
\text { Zamanı } \\
\text { (Saat) }\end{array}$ & $\begin{array}{l}\text { Birim } \\
\text { Zaman } \\
\text { Maliyeti } \\
\text { (TL) }\end{array}$ & $\begin{array}{l}\text { Birim } \\
\text { Maliyet } \\
\text { Yükleme } \\
\text { Oranı }\end{array}$ & $\begin{array}{l}\text { Zaman } \\
\text { Sürücüsü }\end{array}$ & $\begin{array}{l}\text { Zaman } \\
\text { Sürüicü } \\
\text { Miktarı }\end{array}$ & $\begin{array}{l}\text { Toplam } \\
\text { Harcanan } \\
\text { Zaman } \\
\text { (Saat) }\end{array}$ & $\begin{array}{l}\text { Toplam } \\
\text { Faaliyet } \\
\text { Maliyeti } \\
\text { (TL) }\end{array}$ \\
\hline \multirow{5}{*}{$\begin{array}{c}\text { Satın Alma } \\
\text { ve } \\
\text { Üretim } \\
\text { Planlama }\end{array}$} & $\begin{array}{c}\begin{array}{c}\text { Üretim emri } \\
\text { hazırlama }\end{array} \\
\text { Üretim raporu } \\
\text { hazırlama ve } \\
\text { sisteme } \\
\text { girilmesi }\end{array}$ & 0,72 & 29,91 & 21,54 & $\begin{array}{l}\text { Üretim } \\
\text { Emri } \\
\text { Sayıs1 }\end{array}$ & 5.168 & $3.720,96$ & $111.293,91$ \\
\hline & $\begin{array}{c}\begin{array}{c}\text { Hammadde } \\
\text { temin edilmesi }\end{array} \\
\text { Yardımc1 } \\
\text { madde } \\
\text { malzeme temin } \\
\text { edilmesi }\end{array}$ & \multirow{4}{*}{0,34} & \multirow{4}{*}{29,91} & \multirow{4}{*}{10,17} & \multirow{4}{*}{$\begin{array}{l}\text { Satın } \\
\text { Alma } \\
\text { Sipariş } \\
\text { Sayıs1 }\end{array}$} & \multirow{4}{*}{4.422} & \multirow{4}{*}{$1.503,48$} & \multirow{4}{*}{$44.969,09$} \\
\hline & $\begin{array}{c}\text { Tedarikçilerden } \\
\text { fiyat teklifi } \\
\text { alınması ve } \\
\text { değerlendiril- } \\
\text { mesi } \\
\end{array}$ & & & & & & & \\
\hline & $\begin{array}{c}\text { Sözleşme ve } \\
\text { yazışmaların } \\
\text { yapılması }\end{array}$ & & & & & & & \\
\hline & $\begin{array}{c}\text { Tedarikçi } \\
\text { faturaları takibi } \\
\text { ve kontrolü }\end{array}$ & & & & & & & \\
\hline $\begin{array}{c}\text { Toplam } \\
\text { Kullanılan }\end{array}$ & & & & & & & $5.224,44$ & $156.263,00$ \\
\hline $\begin{array}{c}\text { Normal } \\
\text { Kapasite }\end{array}$ & & & & & & & $5.990,40$ & $179.169,12$ \\
\hline $\begin{array}{c}\text { Kullanılmayan } \\
\text { Kapasite }\end{array}$ & & & & & & & 765,96 & $22.906,12$ \\
\hline $\begin{array}{c}\text { Kullanılmayan } \\
\text { Kapasite } \\
\text { Oranı }\end{array}$ & & & & & & & 0,127 & 0,127 \\
\hline
\end{tabular}

ZSFTM sistemine göre faaliyet maliyetlerinin mamullere yüklenmesi Tablo 8'de gösterilmektedir. ZSFTM sistemine göre hesaplanan birim mamul maliyetleri ise Tablo 9'da yer almaktadır. Buna göre örneğin satın alma ve üretim planlama faaliyet havuzuna ilişkin zaman denklemi $\beta 1 . X 1.1 / \mathrm{X} 2+\beta 2 . \mathrm{X} 3.1 / \mathrm{X} 4$ şeklinde belirlenmektedir.

$\beta 1$ : Bir adet üretim emri faaliyetinin gerçekleşmesi için gereken zaman

$\beta 2$ : Bir adet satın alma faaliyeti için gereken zaman

$\mathrm{X} 1$ :Ĕger üretim emri ise (1), değilse (0)

$\mathrm{X} 2$ : Üretim emrine ait bir adet parti içindeki birimlerin sayısı

X3: Eğer satın alma siparişi ise (1), değilse (0)

X4: Satın alma siparişine ait bir adet parti içindeki birimlerin sayısı 
$\mathrm{Bu}$ şekilde işletmenin satın alma ve üretim planlama faaliyet havuzuna ait zaman denklemi aşağıdaki şekilde oluşturulabilir:

SAÜPFHZD: $0,72 . X 1.1 / X 2+0,34 . X 3 \cdot 1 / X 4$

Düzenlenen zaman denklemi sayesinde birim mamul için gereken zaman ile birim kapasite maliyeti çarpılarak mamulün birim maliyeti hesaplanabilmektedir. Aşağıda her bir mamulün ilgili faaliyetlerden almakta oldukları maliyet paylarının hesaplamaları gösterilmektedir:

Üretim emri ve üretim raporu hazırlanması ve sisteme girilmesi faaliyet maliyetlerinin mamullere yüklenmesi:

3 lük noçe eskitme cc

TL) / $127.864 \mathrm{M} 2$

5 lik noçe hk eskitme cc

TL) / $15.283 \mathrm{M} 2$

3 lük light eskitme cc

TL) / 85.497 M2

1.2 lik silver dh ve

TL) / $6.343 \mathrm{M} 2$

1.2 lik sunset $\mathrm{dh}$ ve

TL) / 95.151 M2

1.2 lik sunset eskitme cc

TL) / $23.787 \mathrm{M} 2$
$=(1.383$ Üretim Emri Sayısı X 0,72 saat x 29,91

$=0,23 \mathrm{TL} / \mathrm{M} 2$

$=(403$ Üretim Emri Say1s1 X 0,72 saat x 29,91

$=0,57 \mathrm{TL} / \mathrm{M} 2$

$=(1.074$ Üretim Emri Sayısı X 0,72 saat x 29,91

$=0,27 \mathrm{TL} / \mathrm{M} 2$

$=(154$ Üretim Emri Sayıs1 X 0,72 saat x 29,91

$=0,52 \mathrm{TL} / \mathrm{M} 2$

$=(1.651$ Üretim Emri Sayısı X 0,72 saat x 29,91

$=0,37 \mathrm{TL} / \mathrm{M} 2$

$=(503$ Üretim Emri Sayıs1 X 0,72 saat x 29,91

$=0,46 \mathrm{TL} / \mathrm{M} 2$

Satın alma faaliyet maliyetlerinin mamullere yüklenmesi:

3 lük noçe eskitme cc 29,91 TL) / 127.864 M2

5 lik noçe hk eskitme cc 29,91 TL) / 15.283 M2

3 lük light eskitme cc 29,91 TL) / 85.497 M2

1.2 lik silver dh ve 29,91 TL) / 6.343 M2

1.2 lik sunset dh ve 29,91 TL) / 95.151 M2

1.2 lik sunset eskitme cc 29,91 TL) / 23.787 M2
$=(1.217$ Satın Alma Sipariş Sayısı X 0,34 saat $\mathrm{x}$ $=0,10 \mathrm{TL} / \mathrm{M} 2$

$=(328$ Satın Alma Sipariş Sayısı X 0,34 saat $\mathrm{x}$

$=0,22 \mathrm{TL} / \mathrm{M} 2$

$=(963$ Satın Alma Sipariş Sayısı X 0,34 saat $\mathrm{x}$

$=0,11 \mathrm{TL} / \mathrm{M} 2$

$=(148$ Satın Alma Sipariş Sayısı X 0,34 saat $\mathrm{x}$ $=0,24 \mathrm{TL} / \mathrm{M} 2$

$=(1.408$ Satın Alma Sipariş Sayısı X 0,34 saat $\mathrm{x}$ $=0,15 \mathrm{TL} / \mathrm{M} 2$

$=(358$ Satın Alma Sipariş Sayısı X 0,34 saat $\mathrm{x}$ 


$$
=0,15 \mathrm{TL} / \mathrm{M} 2
$$

Tablo 8. ZSFTM Sisteminde Faaliyet Maliyetlerinin Mamullere Yüklenmesi

\begin{tabular}{|c|c|c|c|c|c|c|c|}
\hline \multirow[b]{2}{*}{$\begin{array}{c}\text { Kaynak } \\
\text { Grubu }\end{array}$} & \multirow[b]{2}{*}{ Faaliyetler } & \multicolumn{6}{|c|}{ Mamul Maliyetleri } \\
\hline & & $\begin{array}{c}3 \text { lük } \\
\text { noçe } \\
\text { eskitme } \\
\text { cc } \\
\end{array}$ & $\begin{array}{c}5 \text { lik } \\
\text { noçe hk } \\
\text { eskitme } \\
\text { cc } \\
\end{array}$ & $\begin{array}{c}3 \text { lük } \\
\text { light } \\
\text { eskitme } \\
\text { cc } \\
\end{array}$ & $\begin{array}{l}\text { 1.2 lik } \\
\text { silver } \\
\text { dh ve }\end{array}$ & $\begin{array}{l}1.2 \text { lik } \\
\text { sunset } \\
\text { dh ve }\end{array}$ & $\begin{array}{c}1.2 \text { lik } \\
\text { sunset } \\
\text { eskitme cc }\end{array}$ \\
\hline \multirow{2}{*}{$\begin{array}{l}\text { Satın Alma ve } \\
\text { Üretim } \\
\text { Planlama }\end{array}$} & $\begin{array}{l}\text { Üretim Emri ve } \\
\text { Üretim Raporu } \\
\text { Faaliyetleri }\end{array}$ & 0,23 & 0,57 & 0,27 & 0,52 & 0,37 & 0,46 \\
\hline & $\begin{array}{l}\text { Satın Alma } \\
\text { Faaliyetleri }\end{array}$ & 0,10 & 0,22 & 0,11 & 0,24 & 0,15 & 0,15 \\
\hline \multicolumn{2}{|c|}{ Ara Toplam } & $\mathbf{0 , 3 3}$ & $\mathbf{0 , 7 9}$ & $\mathbf{0 , 3 8}$ & $\mathbf{0 , 7 6}$ & $\mathbf{0 , 5 2}$ & $\mathbf{0 , 6 1}$ \\
\hline \multirow[b]{2}{*}{ ST Kesim } & Kesim & 1,58 & 2,64 & 0,79 & 2,64 & 2,64 & 2,64 \\
\hline & Makine Hazırlık & 0,20 & 0,48 & 0,23 & 0,42 & 0,32 & 0,39 \\
\hline \multicolumn{2}{|c|}{ Ara Toplam } & $\mathbf{1 , 7 8}$ & 3,12 & $\mathbf{1 , 0 2}$ & 3,06 & 2,96 & $\mathbf{3 , 0 3}$ \\
\hline \multirow[b]{2}{*}{ Yarma } & Yarma & & & & 3,52 & 3,53 & 3,55 \\
\hline & Makine Hazırlık & & & & 0,48 & 0,32 & 0,40 \\
\hline \multicolumn{2}{|c|}{$\begin{array}{l}\text { Ara Toplam } \\
\end{array}$} & & & & 4,00 & $\mathbf{3 , 8 5}$ & 3,95 \\
\hline \multirow[t]{2}{*}{ Silim } & $\begin{array}{l}\text { Cila, honlama, } \\
\text { dolgu, brush vd. }\end{array}$ & 2,83 & 6,59 & 2,83 & 5,65 & 5,65 & 3,28 \\
\hline & Makine Hazırlık & 0,85 & 2,07 & 0,98 & 1,89 & 1,35 & 1,65 \\
\hline \multicolumn{2}{|c|}{ Ara Toplam } & 3,68 & 8,66 & 3,81 & 7,54 & 7,00 & 4,93 \\
\hline \multirow{2}{*}{$\begin{array}{c}\text { Tirmik } \\
\text { Ebatlama } \\
\end{array}$} & Ebatlama & 1,32 & 2,48 & 1,35 & 2,20 & 1,33 & 1,42 \\
\hline & Makine Hazırlık & 0,16 & 0,37 & 0,18 & 0,35 & 0,25 & 0,31 \\
\hline \multicolumn{2}{|c|}{ Ara Toplam } & $\mathbf{1 , 4 8}$ & 2,85 & $\mathbf{1 , 5 3}$ & 2,55 & $\mathbf{1 , 5 8}$ & 1,73 \\
\hline Eskitme & Eskitme & 2,33 & 2,57 & 2,35 & & & 2,48 \\
\hline \multicolumn{2}{|c|}{ Ara Toplam } & 2,33 & 2,57 & 2,35 & & & 2,48 \\
\hline \multirow{2}{*}{ Seleksiyon } & Kalite Kontrol & 1,36 & 1,52 & 1,45 & 1,58 & 1,41 & 1,58 \\
\hline & Paketleme & 0,48 & 0,55 & 0,53 & 0,64 & 0,52 & 0,59 \\
\hline \multicolumn{2}{|c|}{ Ara Toplam } & 1,84 & 2,07 & 1,98 & 2,22 & 1,93 & 2,17 \\
\hline \multirow{3}{*}{$\begin{array}{l}\text { Depo ve } \\
\text { Sevkiyat }\end{array}$} & $\begin{array}{c}\text { Mermerlerin } \\
\text { kesimhaneye } \\
\text { taşınması }\end{array}$ & 0,51 & 1,23 & 0,59 & 1,13 & 0,81 & 0,99 \\
\hline & $\begin{array}{c}\text { Madde ve } \\
\text { malzemenin depoya } \\
\text { yerleştirilmesi }\end{array}$ & 0,17 & 0,38 & 0,20 & 0,41 & 0,26 & 0,27 \\
\hline & $\begin{array}{c}\text { Mamullerin depoya } \\
\text { yerleştirilmesi }\end{array}$ & 0,38 & 0,93 & 0,44 & 0,86 & 0,61 & 0,75 \\
\hline \multicolumn{2}{|c|}{ Ara Toplam } & 1,06 & 2,54 & 1,23 & 2,40 & 1,68 & 2,01 \\
\hline \multicolumn{2}{|c|}{ GENEL TOPLAM } & 12,50 & 22,60 & 12,30 & 22,53 & 19,52 & 20,91 \\
\hline
\end{tabular}

Tablo 9. X Traverten A.Ş. Zaman Sürücülü Faaliyet Tabanlı Birim Mamul Maliyetleri

\begin{tabular}{|c|c|c|c|c|c|c|}
\hline \multirow[t]{2}{*}{ Maliyetler } & \multicolumn{6}{|c|}{ Mamul Maliyetleri } \\
\hline & $\begin{array}{l}3 \text { lük noçe } \\
\text { eskitme cc }\end{array}$ & $\begin{array}{c}5 \text { lik noçe hk } \\
\text { eskitme cc }\end{array}$ & $\begin{array}{l}3 \text { lük light } \\
\text { eskitme cc }\end{array}$ & $\begin{array}{c}1.2 \text { lik } \\
\text { silver dh } \\
\text { vc }\end{array}$ & $\begin{array}{c}1.2 \text { lik } \\
\text { sunset dh } \\
\text { vc }\end{array}$ & $\begin{array}{l}1.2 \text { lik sunset } \\
\text { eskitme cc }\end{array}$ \\
\hline $\begin{array}{l}\text { Direkt İlk } \\
\text { Madde ve } \\
\text { Malzeme } \\
\text { Maliyeti } \\
\text { (DiMM) }\end{array}$ & 6.47 & 10,25 & 6,47 & 20,00 & 3,50 & 3,50 \\
\hline $\begin{array}{l}\text { Direkt İşçilik } \\
\text { Maliyeti (DİŞ) }\end{array}$ & 5,03 & 9,22 & 6,18 & 10,48 & 9,75 & 13,62 \\
\hline $\begin{array}{l}\text { Genel Üretim } \\
\text { Maliyetleri } \\
\text { (GÜM) }\end{array}$ & 12,50 & 22,60 & 12,30 & 22,53 & 19,52 & 20,91 \\
\hline $\begin{array}{l}\text { Birim Mamul } \\
\text { Maliyeti }\end{array}$ & 24,00 & 42,07 & 24,95 & 53,01 & 32,77 & 38,03 \\
\hline
\end{tabular}




\subsection{EIde Edilen Sonuçların Değerlendirilmesi}

Bu çalışmada modern maliyetleme sistemlerinden "Zaman Sürücülü Faaliyet Tabanlı Maliyetleme Sistemi”nin örnek işletme olarak seçilen ve Denizli' de faaliyetlerini sürdürmekte olan X Traverten A.Ş. işletmesinde uygulanması sonucunda ulaşılan mamul maliyetlerine ilişkin hesaplamalara yer verilmiştir. $\mathrm{Bu}$ aşamada, literatürde yer alan uygulamalar incelenerek işletmenin mevcut kaynaklarının kapasiteleri ve işletmede gerçekleştirilen faaliyetlerin standart süreleri, çalışanlarla ve yöneticilerle yapılan görüşmeler ve doğrudan yapılan gözlemler sonucunda elde edilmiştir. Elde edilen bilgiler ışığında işletmenin ZSFTM sistemine göre mamul maliyetleri hesaplanmıştır. Aynı zamanda işletmenin sahip olduğu kaynak gruplarının ne ölçüde verimli çalıştığı gözlemlenebilmekte ve yönetime işletmenin kaynak gruplarının kapasite kullanımı hakkında bilgi verilebilmektedir. Bu sayede, işletme yöneticileri kapasitesini verimli kullanamayan kaynak grupları hakkında bilgi sahibi olmakta ve bunun önüne geçebilmek adına gerekli kararları verebilme imkanına sahip olabilmektedir.

$\mathrm{Bu}$ çalışmada ulaşılan sonuçlardan birisi de, 1.2 lik mamullerin 3 lük ve 5 lik mamullerin üretim süreçlerine ek olarak yarma faaliyetinden geçmeleri ve dolayısı ile 3 lük eskitme mamullerine göre genel üretim maliyetlerinden daha fazla pay almakta olmalarıdır. Bunun nedeni 3 lük ve 5 lik mamuller yarma makinesinde işlem görmeden sadece ST makinelerinde kesilmekte ve sonrasında mamulün özelliğine göre diğer üretim süreçlerinden geçmekte iken 1.2 lik mamuller ST makinelerinde kesildikten sonra yarma makinelerinde tekrar ikiye kesilmektedir. Ayrıca, dh kodlu mamuller eskitme kodlu mamullere kıyasla yapısı gereği daha uzun süre silim makinelerinde işlem görmekte iken eskitme kodlu mamuller gibi eskitme faaliyetinden maliyet payı almamaktadır. Bunun yanı sıra 5 lik noçe hk eskitme cc mamulünün 3 lük eskitme mamullerine kıyasla genel üretim maliyetlerinden daha fazla pay almaktadır. Bunun sebebi ise bu mamulün özelliği gereği diğer mamullerin üretim süreçlerine ek olarak bulnoz makinelerinde işlem görmesi gerekmektedir. Diğer 5 mamul bulnoz işleminden geçmemektedir ancak 5 lik noçe hk eskitme cc mamulü özelliği gereği silim faaliyeti içerisinde bulnoz işlemine tabi tutulmaktadır. Bu bilgiler 1şı̆̆gnda hesaplanan maliyetler incelenecek olursa işletmede gerçekleşen faaliyetlerden daha fazla yararlanan, bir başka deyişle işletme kaynaklarını daha fazla tüketen mamullerin genel üretim maliyetlerinden de daha fazla pay almakta oldukları görülmektedir. Bu durum da, ZSFTM sistemlerinin mantığıyla uyumlu olmaktadır. Yukarıda yapılan açıklamalar ışığında, ZSFTM literatürde bahsedildiği şekliyle işletme yöneticilerine yalnızca doğru ve gerçekçi maliyet bilgisi sunmakla kalmayıp aynı zamanda etkili bir kapasite yönetimi hususunda bilgi verebilmektedir.

\section{SONUÇ}

Günümüz iş ortamlarının belirleyici özelliklerinden biri olan küreselleşme ve küreselleşmenin getirdiği artan şiddetli rekabet olgusu, gerek hizmet gerekse sanayi işletmelerini varlıklarını sürdürebilmek, karlılıklarını korumak ve arttırmak, pazar hakimiyetlerini kaybetmemek amacı ile yeni çareler aramaya yöneltmektedir. Mal ve hizmetlerin fiyatı çoğunlukla piyasada belirlenmekte ve işletmelerin belirlenen fiyatların üzerinde bir fiyat belirlemeleri çoğu zaman mümkün olmamaktadır. Bu nedenle işletme yöneticileri dikkatlerini satış fiyatından ziyade mamul ve hizmet maliyetlerine doğrultmaktadır. Üretilen mamul ve/veya hizmetlerin kalitesinden ödün vermeden 
maliyetlerinde iyileştirme yapmayı hedefleyen işletmeler bu süreçte doğru ve zamanında üretilen maliyet bilgisine her zamankinden daha fazla ihtiyaç duymaktadır. İşletmelerde alınacak olan bütün stratejik yönetim kararında maliyet bilgileri oldukça önemli bir role sahiptir. Değişen ve gelişen yeni üretim ortamlarında faaliyet göstermekte olan ve yoğun küresel rekabete maruz kalan işletmelerde yöneticiler, bünyelerinde üretilen mamul ve hizmetlerin maliyet yapısında ortaya çıkan değişiklikleri anlayabilmek ve işletmede gerçekleşen süreçlere daha iyi hakim olabilmek için yeni ve güncel maliyetleme modellerine gereksinim duymaktadır.

Geleneksel FTM sisteminin uygulamada karşılaştığı bir takım güçlükler neticesinde bilim insanları sistemin eksikliklerini giderebilecek yeni bir sistem arayışına girmişlerdir. Bunun sonucunda ZSFTM sistemi geliştirilmiştir. ZSFTM sisteminin geliştirilmesindeki amaç geleneksel FTM sisteminin iyileştirilmesi ve kolaylaştırılması olmaktadır. Yeni sistemde prensip halen geçerlidir, işletmelerde faaliyetler kaynakları ve mamuller de faaliyetleri tüketmektedir. Geleneksel FTM sisteminden farklı olarak maliyet sürücüsü olarak yalnızca "zaman" dikkate alınmaktadır. ZSFTM sisteminin işleyişi, işletmede gerçekleşen faaliyetlerin yerine getirilebilmesi için ihtiyaç duyulan zaman ile işletme kaynaklarının mevcut kapasitelerinin birim zaman maliyetinin belirlenmesi yolu ile gerçekleşmektedir. Maliyet sürücüsü olarak sürenin dikkate alınması sayesinde hatalı maliyet sürücüsü seçiminden kaynaklanabilecek ölçümleme hatalarının da önüne geçilebilmektedir. Aynı zamanda sistemin güncellenmesi de nispeten daha kolay olmaktadır. Bunun dışında, ZSFTM sistemi geleneksel FTM sisteminden farklı olarak normal kapasiteyi kullanmakta ve bu haliyle işletme yöneticilerine kapasite kullanımında etkinlik ve verimlilik sağlanması hususunda yardımc1 olabilecek bilgiler üretebilmektedir. FTM sistemine getirilen eleştirilerden bir diğeri olan zaman alıcı ve maliyetli anket ve mülakat süreçleri ZSFTM sisteminde yerini doğrudan gözlem yolu ile sürelerin belirlenmesi yöntemine bırakmaktadır. $\mathrm{Bu}$ hali ile de FTM sisteminin bir eksikliğini daha ortadan kaldırıldığı düşünülmektedir.

Ülkemizde mermer sektöründe faaliyet gösteren işletmeler çoğunlukla işlenip katma değer kazanan fayansları üretip satmak yerine ocaklardan blok şeklinde çıkarılan mermerleri hiçbir işlemden geçirmeden doğrudan satmayı tercih etmektedir. Bu durumun başlıca nedenlerinden biri, sektörde faaliyet gösteren işletmelerin büyük bir çoğunluğunun küçük ölçekli işletmeler olması ve gerekli olan teknoloji yatırımını gerçekleştirememeleridir. Bu nedenle sektörde faaliyet gösteren işletmelerin karlılıkları ve rekabet güçleri düşük kalmaktadır. Bununla birlikte ülkemiz mermer kaynakları bakımında oldukça zengin bir konumdadır. İşletmeler ham mermeri doğrudan satmak yerine işleyip katma değer açısından zengin mamuller üretip sattıkları takdirde karlılıkları oldukça artacaktır. Bu anlamda mermer sektörü yüksek potansiyele sahip olan bir sektör konumundadır.

ZSFTM sistemi ile ilgili literatür çalışmaları incelendiğinde yöntemin ağırlıklı olarak hizmet işletmelerinde kullanıldığ 1 görülmektedir. Mermer işletmelerinde maliyet hesaplamaları geleneksel ve tecrübi yöntemlere dayanarak gerçekleştirilmektedir. İşletme yöneticileri doğru ve güncel maliyet bilgisine çoklukla erişememekte ve bu durum rekabet güçlerini sınırlandırmaktadır. Bu bağlamda yapılan çalışmanın hem bir üretim işletmesinde gerçekleştirilmiş olması sebebi ile hem de farklı ve ilgi çekici bir sektör olarak mermer sektöründe gerçekleştirilmiş olması sebebi ile literatüre katkı sağlayacağı düşünülmektedir. 


\section{KAYNAKLAR}

Bharara, A. -Lee, C.Y. (1996), "Implementation of an Activity-Based Costing System in a Small Manifacturing Company”, International Journal of Production Research, Vol. 34, Issue 4, pp. 1109-1130

Cengiz, E. (2011), "Faaliyet Tabanlı Maliyetleme ve Sürece Dayalı Faaliyet Tabanlı Maliyetleme Arasındaki Farklar - Bir Mobilya Üreticisi Firmada Vaka Çalışması", Muhasebe ve Finansman Dergisi, Issue 50, pp. 33-58

Cokins, G. (2015), "Measuring and Managing Customer Profitability", Strategic Finance, Vol.97, Issue 2, pp. 23-29

Dalc1, İ. -Tanış, V. -Koşan, L. (2010), “Customer Profitability Analysis with Time- Driven Activity- Based Costing: A Case Study in a Hotel", International Journal of Contemporary Hospitality Management., Vol.22, Issue 5, pp. 609-637

Demeere, N. -Stouthuysen, K. -Roodhooft, F. (2009), “Time-Driven Activity-Based Costing in an Outpatient Clinic Environment: Development, Relevance and Managerial Impact", Health Policy, Vol. 92, Issue 2-3, pp. 296-304

Erdoğan, N. -Saban, M. (2010), Maliyet ve Yönetim Muhasebesi 5. Bask1 İstanbul: Beta Basım Yayım

Erkuş, H. -Aksu İ. -Turan E. (2014), "Kaynak Tüketim Muhasebesinin Diğer Maliyet Sistemleri ile Karşılaştırılması", Muhasebe ve Vergi Uygulamaları Dergisi, Vol.7, Issue 2, pp. 15-26

Gersil, A. (2007), "Üretim Sistemleri ve Teknolojilerindeki Gelişmelerin ve Küreselleşmenin Geleneksel Maliyet Muhasebesine Etkileri”, Ankara Üniversitesi SBF Dergisi, Vol. 62, Issue 4, pp. 107-123

Hansen, R. -Mowen, M. (2011), Introduction to Cost Accounting. 1.Edition. South-Western Cengage Learning

Kaygusuz, S.Y. (2007), "Faaliyet Tabanlı Maliyet-Hacim-Kar Analizi", Muhasebe ve Finansman Dergisi, Issue 33, pp. 139-150

Kaygusuzoğlu, M. (2010), "Üretim Maliyetlerindeki Yapısal Değişmelerin Nedenleri ve Maliyetleme Kararlarına Etkileri”, Elektronik Sosyal Bilimler Dergisi, Vol. 9, Issue 34, pp. $240-258$

Kim, Y. -Han, S. -Yi, J. -Chang, S. (2016), "Supply Chain Cost Model for Prefabricated Building Material Based on Time-Driven Activity-Based Costing”, Canadian Journal of Civil Engineering, Vol.43, Issue 4, pp. 287-293

Namazi, M. (2016), "Time-Driven Activity-Based Costing: Theory, Applications and Limitations", Iranian Journal of Management Studies, Vol.9, Issue 3, pp. 457-482 
Onat, O.K. -Anitsal İ. -Anitsal M.M. (2014), "Activity Based Costing in Services Industry: A Conceptual Framework for Entrepreneurs", Entrepreneurial Executive, Issue 19, pp. $149-167$

Özkan, S. - Karaibrahimoğlu, Y.Z. (2013), "Activity-Based Costing Approach in the Measurement of Cost of Quality in SME's : A Case Study", Total Quality Management \& Business Excellence, Vol. 24, Issue 4, pp. $420-431$

Özyürek, H. - Dinç, Y. (2014), "Son Yıllarda Maliyet Dağıtımında Kullanılan Yöntemler ve Zamana Dayalı Faaliyet Tabanlı Maliyetleme Olay Çalışması", Cumhuriyet Üniversitesi İktisadi ve İdari Bilimler Fakültesi Dergisi, Vol.15, Issue 1, pp. 345-364.

Posey, I.A. - Roth, H.P. (1986), Study Guide for Cost Accounting. 3.Edition. Addison-Wesley Publishing Company

Reddy, K. -Venter, H.S. -Olivier, M.S. (2012), "Using Time-Driven Activity-Based Costing to Manage Digital Forensic Readiness in Large Organisations", Information Systems Frontiers, Vol. 14, Issue 5, pp. 1061-1077

Stratton, W.O. -Desroches, D. -Lawson, R.A. -Hatch, T. (2009), "Activity-Based Costing : Is It Still Relevant?”, Management Accounting Quarterly, Vol. 10 Issue 3, pp. 31-40

Todorovic, M. (2016), "Organizational and Methodological Aspects of Time-Driven Activity Based Costing", Teme Casopis Za Drustvene Nauke, Vol. 40, Issue 1, pp. 203-216

Tsai, W.H. - Chen, H.C. -Liu, J.Y. -Chen, S.P. -Shen, Y.S. (2011), "Using Activity-Based Costing to Evaluate Capital Investments for Green Manufacturing Systems", International Journal of Production Research, Vol. 49, Issue 24, pp. 7275-7292

Yaşar, R.Ş. (2017), "Zaman Esaslı Faaliyet Tabanlı Maliyetleme Yöntemi ile Konteyner Terminallerinde Maliyet Analizi” Muhasebe ve Finansman Dergisi, Issue 73, pp. 203228

Yükçü, S. - Gönen, S. (2009), "Zaman Esaslı Faaliyete Dayalı Maliyetleme Yaklaşımının Otomobil Parçaları Üreten Bir İşletmede Uygulanması", Muhasebe ve Denetime Bakış, Vol.9, Issue 28, pp. 19-31 